\title{
New Promising Varieties of Spring Hard Wheat as the Best Raw Material for Pasta Production
}

\author{
Elena Zhiganova, Madina Sadigova*, and Ksenia Smirnova \\ Saratov State Agrarian University named after N.I. Vavilov, 1 Teatralnaya Ploshchad, Saratov, \\ 410012, Russia
}

\begin{abstract}
Pasta is the most demanded product on the market, although Russia is not the world's leader in per capita consumption. This is due to the fact that the main raw material for pasta products (up to $80 \%$ ) is bakery flour. For production of pasta all over the world, durum wheat grains are used, which have distinctive characteristics from soft wheat. These include: grain nature not less than $800 \mathrm{~g} / \mathrm{l}$, glassiness of $80 \%$, protein content of $15 \%$, IDK 4.5 units by device (Glutograph-E Brabender), color index by Minolta device is $22 \mathrm{cu}$. For more than a century, Saratov breeders have been creating durum wheat varieties with high technological potential. This article discusses new varieties of the laboratory for selection and seed production of spring durum wheat of the Federal State Budgetary Scientific Institution Federal Agrarian Scientific Center of South-East: Luch 25, Pamyati Vasilchuka and Tamara - varieties that are promising for use in pasta production as raw materials that meet high international quality standards.
\end{abstract}

\section{Introduction}

In the context of a pandemic, self-isolation and the 2020 crisis, pasta for many people, as before, replaced more expensive types of side dishes, so their sales increased significantly. In 2019, per capita consumption was $9.9 \mathrm{~kg}$ against $7.8 \mathrm{~kg}$ in 2015 (an increase of $27 \%$ ). The share of group A pasta in the total consumption over the past 10 years has grown by 1.5 times (from $30 \%$ to $45 \%$ ). This was facilitated by the positioning of durum wheat pasta as one of the products for a healthy diet, as well as an integral part of the diet due to its organic compounds. Durum wheat grain is rich in vitamins and minerals. Durum wheat flour and, accordingly, pasta made from it have a lower glycemic index than soft wheat, are easily digested, and active carbohydrates and useful minerals improve digestion and metabolism, which has a positive effect on human health. Such pasta contains practically no fat, therefore, it does not lead to excess weight gain. Products made of durum wheat (group A) are considered by world nutritionists as the most balanced product for the daily diet, providing a long-term feeling of satiety $[1,2,3]$.

The main raw materials for production of pasta all over the world are durum wheat varieties (Triticum durum Desf), which is explained by the peculiarities of durum wheat varieties: high glassiness and protein content, a large amount and quality of gluten, as well

\footnotetext{
*Corresponding author: sadigova.madina@yandex.ru
} 
as the content of carotenoids [2,3]. The main cultivation areas in the world are located in Portugal, Italy and Spain, USA, Russia, Kazakhstan. This crop ranks second in cultivation, after soft wheat, and occupies about $7-10 \%$ of the total sown area in the world. Durum production in the world is about 30-35 million tons per year [4,5]. In Italy, for example, the law prohibits production of pasta from farina (grains) of soft (bread) wheat. In developed countries, such as the USA, Germany, and etc., pasta is made of durum wheat grits, and alternative options are used only for special, mainly dietary, purposes. However, in Russia, in contrast to Italy, the quality of pasta is treated with an open mind, therefore, up to $80 \%$ of finished products are made of bakery flour. Basically, these are products of class "B" [1]. For production of macaroni products of the "A" group, it is enough to add $30 \%$ grains of durum wheat varieties. This significantly affects the quality of the finished product, its organoleptic and physicochemical qualities.

To remedy this situation, breeders have been breeding new high-quality varieties of spring durum wheat that are resistant to the climatic conditions of the Saratov region for many years. Since 1911, in Research Institute of Agriculture of Southeast such distinguished scientists as academician G.K. Meister, Doctor of Agricultural Sciences, Professor A.P. Shekhurdin, Doctor of Agricultural Sciences V.N. Mamontova, Doctor of Agricultural Sciences L.G. Ilyina tried to solve this issue. Since 1984, a separate laboratory for selection and seed production of spring durum wheat was arranged, which was headed by Doctor of Agricultural Sciences, Professor, Corresponding Member of RAAS N.S. Vasilchuk. His disciples continue his work. During this time, 15 varieties of spring durum wheat with high quality indicators were created [6].

The purpose of the study is to consider the quality of new varieties of spring durum wheat bred by the Federal Agrarian Scientific Center of South-East for 2019-2020, to substantiate the prospects of their use for the production of pasta.

\section{Methods}

Evaluation of the quality of durum wheat grain is a difficult task, this is due to the specific requirements for the pasta dough, which is explained by the peculiarities of pasta production. Grits shall absorb a small amount of water during kneading, but at the same time form an elastic and non-sticky dough with certain rheological properties for forming a semi-finished product, not crushing during cutting and drying. The dried dough shall represent a dense (glassy in the products in a break) mass, possessing sufficient mechanical strength, not cracking, not brittle. Finished products shall be of a pleasant yellow color, have a smooth surface and not lose their shape during cooking [5, 7]. Therefore, the indicators of grain quality shall be approached responsibly.

Producers of pasta flour have the following requirements for the quality of grain in accordance with GOST 9353-2016 for durum wheat of the 1st class: glassiness not less than $85 \%$; protein content more than $13.5 \%$, gluten not less than $28 \%$; quality of raw gluten from 18 to 102 IDK units, but in production they use wheat of at least 2 quality groups, or rather, at least 42 IDK units; grain nature is more than $770 \mathrm{~g} / \mathrm{l}$; the content of carotenoids is not less than $5 \mathrm{mg} / \mathrm{kg}$; weight of 1,000 grains is $40-50 \mathrm{~g}$. The quality of the gluten affects the duration of cooking, the coefficients of increase in mass, the volume and strength of finished products, the loss of dry matter of products during the cooking process, as well as adhesion. The nature of the grain shows the degree of fulfillment of the weevil; this indicator is of great technological importance, since affects the flour yield. The mass of 1,000 grains is also an important indicator of the grain quality of durum wheat. This indicator also affects the yield of crumbs (semolina) during grinding. SDS - sedimentation characterizes flour swelling, depends directly on the quantity and quality of gluten, therefore, it is a quality indicator of grain. The vitreousness of the grain characterizes the 
consistency of its endosperm, indicates the protein or starchy nature of the grain. In accordance with the standards of the pasta industry, the yellowness of semolina, due to the high content of carotenoids, is highly valued [1,5,7-10]. For example, the Barilla-Rus company, one of the world's largest producers of pasta and spaghetti, makes the following requirements for the main parameters of flour (at least): grain nature of $800 \mathrm{~g} / \mathrm{l}$, glassiness of $80 \%$, protein content of $15 \%$, IDK 4.5 units by device (Glutograph-E Brabender), color index by Minolta device is $22 \mathrm{cu}$. Therefore, the indicators of the Russian standard for durum wheat and global producers differ from each other. Indicators for imported factories are higher than our standards. This leads to a decrease in demand for domestic raw materials.

\section{Results}

The objects of the study are varieties of the Federal Agrarian Scientific Center of SouthEast: Tamara (2021), Pamyati Vasilchuka (2020), Luch 25 (2014). Determination of grain quality indicators was carried out according to generally accepted methods for durum wheat (V.N. Remeslo, 1971; N.S. Vasilchuk, 2001), data for 2019 - 2020 [11,12]. For the analysis, the overall correlation between the quality indicators for the varieties was calculated. The data are shown in Table 1.

Table 1. Correlation links of SDS - sedimentation with the physicochemical properties of grain and yield for 2019-2020.

\begin{tabular}{|l|c|c|c|c|c|c|c|}
\hline \multicolumn{1}{|c|}{ Indicator } & $\begin{array}{c}\text { Product } \\
\text { ivity, } \\
\text { t/ha }\end{array}$ & $\begin{array}{c}\text { Protein } \\
\text { content, } \\
\text { \% }\end{array}$ & $\begin{array}{c}\text { Gluten } \\
\text { content, } \\
\text { \% }\end{array}$ & $\begin{array}{c}\text { IDK } \\
\text { unit }\end{array}$ & $\begin{array}{c}\text { Nature, } \\
\text { g/l }\end{array}$ & $\begin{array}{c}\text { Weight } \\
\text { of 1,000 } \\
\text { grains, } \\
\text { g }\end{array}$ & $\begin{array}{c}\text { Glassines } \\
\text { s, \% }\end{array}$ \\
\hline $\begin{array}{l}\text { SDS - } \\
\text { sedimentatio } \\
\text { n, ml }\end{array}$ & 0.94 & -0.45 & -0.44 & -0.75 & -0.98 & -0.14 & -1 \\
\hline $\begin{array}{l}\text { Productivity, } \\
\text { t/ha }\end{array}$ & 1.00 & -0.72 & -0.71 & -0.93 & -0.99 & -0.46 & -0.94 \\
\hline $\begin{array}{l}\text { Protein } \\
\text { content, \% }\end{array}$ & -0.72 & 1.00 & 0.99 & 0.93 & 0.62 & 0.95 & 0.45 \\
\hline $\begin{array}{l}\text { Gluten } \\
\text { content, \% }\end{array}$ & -0.71 & 0.99 & 1.00 & 0.29 & 0.61 & 0.95 & 0.44 \\
\hline IDK units & -0.92 & 0.93 & 0.92 & 1.00 & 0.87 & 0.76 & 0.75 \\
\hline Nature, g/l & -0.99 & 0.62 & 0.61 & 0.87 & 1.00 & 0.34 & 0.98 \\
\hline $\begin{array}{l}\text { Weight of } \\
\mathbf{1 , 0 0 0} \text { grains, } \\
\text { g }\end{array}$ & -0.46 & 0.94 & 0.95 & 0.76 & 0.34 & 1.00 & 0.14 \\
\hline $\begin{array}{l}\text { Glassiness, } \\
\text { \% }\end{array}$ & 0.94 & 0.45 & 0.44 & 0.75 & 0.98 & 0.14 & 1.00 \\
\hline
\end{tabular}

From the data in the table, an inversely proportional relationship between sedimentation and glassiness of grain is visible and is $(-1)$, as well as the quality of gluten $(-0.98)$. SDS sedimentation has long been used to determine the quality of grain, or rather the quality of its gluten, already at the early stages of breeding. Namely, a close positive correlation was found between the SDS sedimentation index of durum wheat samples and such important parameters of the dough farinogram as kneading time, stability (resistance to mixing) of the paste, valorimetric number and visual assessment of the farinogram curve in points [9].

The protein content and the amount of gluten are two completely dependent indicators. The higher the protein content in semolina and the stronger and more elastic the gluten, the 
more resistant the pasta to overcooking and the higher their culinary and nutritional benefits. This is especially important in the production of recently popular thin products spaghetti. There was a direct relationship between the protein content and the amount and quality of gluten 0.99 and 0.93 , respectively (Table 1 ).

Indicators of the mass of 1,000 grains and the nature of the grain are also qualitative indicators, since directly display protein and gluten content. This table shows a direct dependence of the mass of grains and gluten, as well as the nature of grain and gluten, the correlation is 0.95 . Despite the fact that these two indicators, as can be seen from the table, correlate little, only 0.34 . By the nature of the grain, one can judge the glassiness of the grain, because these indicators are directly proportional to each other. The correlation of these indicators is 0.98 . Therefore, at the initial stages of laboratory research, it is already possible to understand the quality of grain and predict the further use of this raw material in the production of pasta.

Another important indicator of the quality of grain for production of pasta is the amount of carotenoids. It is known that the characteristic golden-yellow color of high-quality pasta products is due to presence in the endosperm of durum wheat of a sufficiently large amount of carotenoid pigments that have antioxidant properties useful for humans. The group of carotenoids includes substances colored yellow or orange. The most famous representatives of carotenoids are carotenes. These are pigments that give a specific color to carrots, tomatoes, citrus fruits, and etc., as well as luteins, which are contained, along with other components of carotenoids, both in grain and in green parts of plants. Carotenes are the substances from which vitamin $\mathrm{A}$ is formed. One carotene molecule forms one or two vitamin A molecules [13].

This indicator affects the final color of the product. Figure 1 shows data on the content of carotenoids in the grain of the studied durum wheat varieties.

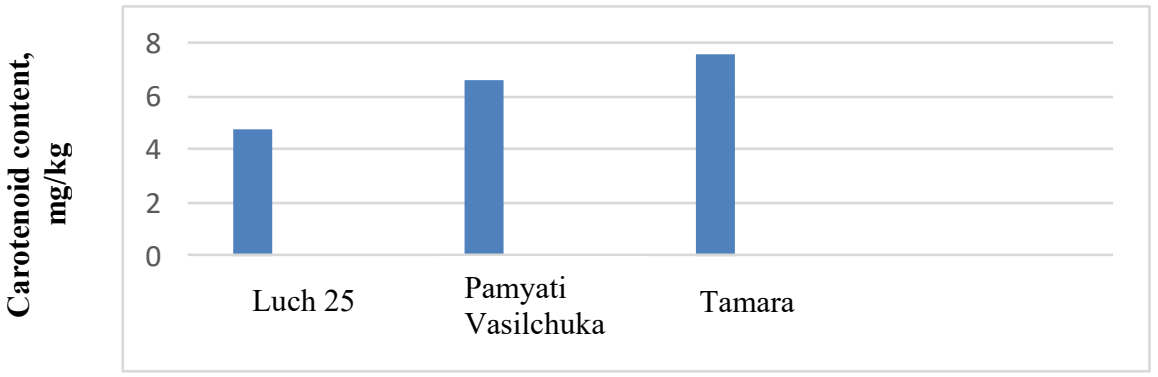

Fig. 1. Carotenoid content in varieties, $\mathrm{mg} / \mathrm{kg}$.

In the conditions of the Volga region, a good golden-yellow color of semolina and finished pasta is ensured when the content of carotenoid pigments in the grain is not less than $4.0-4.5 \mathrm{mg} / \mathrm{kg}$. However, during storage of grain and semolina, when grinding grain and kneading dough, their rapid oxidation occurs, associated with the activity of the lipoxygenase enzyme, durum wheat varieties with an even higher content of carotenoid pigments (up to $7-8$ and more $\mathrm{mg} / \mathrm{kg}$ ) are necessary [13]. According to the requirements of world pasta producers, the yellowness of the crumbs (semolina) in the grain of durum wheat varieties shall be at least $22 \mathrm{cu}$ (device Spekol-10, Minolta-Konika), which corresponds to the content of carotenoid pigments not less than $6.0 \mathrm{mg} / \mathrm{kg}$. 


\section{Discussion}

Variety Luch 25 is a promising high-yielding variety 2.4-3.0 t/ha, it is recommended for cultivation in the left-bank areas of the region. The average protein content in this type of grain was $15.2 \%$. The gluten content is $30.2 \%$, the quality is 83 units, the IDK is characterized as moderately weak. This indicator will provide good structural and mechanical properties of pasta. The nature is $800 \mathrm{~g} / \mathrm{l}$, while the mass of 1,000 grains is $42.9 \mathrm{~g}$, which indicates that the grain is full, thereby contributing to a greater output of crumbs. However, the low content of carotenoids is $4.7 \mathrm{mg} / \mathrm{kg}$ (Fig. 1). SDS sedimentation of this grade is $52 \mathrm{~mm}$, while the vitreousness is $94 \%$. This variety has long been entered into the register and is successfully used in the Volga region.

The Pamyati Vasilchuka variety differs in that it is not affected by the "black germ", which is a great advantage for pasta production, because it provides a clean, without gray impurities (specks) color of the product. High-yielding variety is $2.5 \mathrm{t} / \mathrm{ha}$. Gluten content of $25.6 \%$, quality is 66 IDK units, which provides high cooking properties of products. The main feature is the excellent rheological properties of the dough in the process of kneading semolina. Therefore, this variety is excellent for thin spaghetti $[14,15]$. The protein content is $14.5 \%$, the mass of 1,000 grains is $40.5 \mathrm{~g}$, which is confirmed by the high grain nature of $795 \mathrm{~g} / \mathrm{l}$. SDS - sedimentation of this grade is $54 \mathrm{~mm}$. The glassiness index is $93 \%$. The high content of carotenoids is $6.6 \mathrm{mg} / \mathrm{kg}$, which gives the products a pleasant yellow-amber color. The Pamyati Vasilchuka variety has a high content of carotenoid pigments at the level of $6.5 \mathrm{mg} / \mathrm{kg}$, which will make it possible to obtain class A products of modern commercial quality. The color of pasta - products and their quality from semolina of a new variety are estimated at 9 points. The amount of yellow pigment (carotenoids) in the grain determines the intensity of the spaghetti color. Products with a dark amber or golden color are considered to be of the highest quality. This variety has been entered in the register since 2020, and is at the stage of multiplying the seed base.

Tamara variety is a new promising variety of the Federal Agrarian Scientific Center of South-East selection. Productivity of $2.5-3.0 \mathrm{t} / \mathrm{ha}$, high grain quality $808 \mathrm{~g} / \mathrm{l}$ with a 1,000 grain mass of $41.6 \mathrm{~g}$, which will provide a large output of crumbs. Gluten content is $29.0 \%$; quality is 86 IDK units. SDS - sedimentation of this grade is $44 \mathrm{~mm}$. High glassiness is within $98 \%$. The variety with the highest carotenoid content of $7.6 \mathrm{mg} / \mathrm{kg}$, which will also give the products a pleasant yellow-amber color [11,13,15]. All these indicators indicate a high potential for using this variety for the production of spaghetti. The variety is still under strain testing and will be added to the variety register in 2022 .

\section{Conclusion}

Varieties of Pamyati Vasilchuka and Tamara have high technological quality indicators for use in the production of pasta. The obtained indicators for 2019-2020 fully comply with modern international requirements for raw materials for pasta. High content of gluten 25.5$30.2 \%$ and its quality from 66 IDK units will provide a smooth structure, good structural and mechanical properties of finished products. This suggests that the finished product from this raw material will have good rheological properties. The mass of 1,000 grains is in the range of $40.5-42.9 \mathrm{~g}$, the nature of the grain is 795-808 g/l, as well as a high glassiness of 93-98 \%, which will provide a greater yield of high-quality crumbs for pasta dough. A pasta made of grain of this quality will not boil too much, and will also retain all the useful properties of the product. A high content of carotenoids up to $7.9 \mathrm{mg} / \mathrm{kg}$ will give the products an attractive amber-yellow color, as well as provide a sufficient residual amount of carotenoids in the product after cooking. Pasta of these varieties of spring durum wheat 
will have all the main indicators of product quality, retain useful properties, and also have a pleasant color of the finished product.

\section{References}

1. M. A. Rozova, Dostizheniya nauki i tekhniki APK, 33, 11 (2019)

2. V.A. Timofeeva, Tovarovedenie prodovol'stvennyh tovarov (Rostov-na-Donu Feniks, 2005)

3. YU. V. Savina, Strategii i trendy razvitiya nauki v sovremennyh usloviyah, 1, 3 (2017)

4. A. G. Lozhkin, A. E. Makushev, O. A. Vasiliev, IOP Conference Series: Earth and Environmental Science (2019)

5. V. Natoli, P. Malchikov, P. De Vita, Comprehensible Science: ICCS: International Conference on Comprehensible Science: Conference proceedings (2021)

6. N. S. Vasil'chuk, S. N. Gaponov, L. V. Eremenko, Dostizheniya nauki i tekhniki APK, 5 (2010)

7. S. A. Leonova, Niva Povolzh', 15, 2 (2010)

8. N. S. Vasil'chuk, S. N. Gaponov, L. V. Eremenko, Agrarnyj vestnik YUgo-Vostoka, 3,3 (2009)

9. M.A. Leshchenko, Dostizheniya nauki i tekhniki APK, 1 (2015)

10. M. Joubert, M. H. Morel, V. Lullien-Pellerin, Cereal Chemistry, 95, 3 (2018)

11. S. N. Gaponov, G. I. SHutareva, N. M. Cetva, Agrarnyj vestnik YUgo-Vostoka, 23, 3 (2019)

12. N. S. Vasil'chuk (Saratov, «Novaya gazeta», 2001)

13. N. S. Vasil'chuk, S. N. Gaponov, L. V. Eremenko (Saratov, OOO «Rakurs», 2009)

14. S.N. Gaponov, V.M. Popova, G.I. SHutareva, I.S. Cetva, N.M. Cetva, T.M. Parshikova, Agrarnyj vestnik YUgo-Vostoka, 20, 3 (2018)

15. S.N. Gaponov, G.I. SHutareva, N.M. Cetva, I.S. Cetva, I.V. Milovanov, Zernovoe hozyajstvo Rossii, 67, 1 (2020) 